\title{
Contamination by heavy metals in soils in the neighbourhood of a scrapyard of discarded vehicles
}

\author{
A. Chicharro Martín ${ }^{a}$, V. Cala Rivero ${ }^{\text {b,* }}$, M.T. Larrea Marín ${ }^{c}$ \\ ${ }^{a}$ Centro de Espectrometría Atómica, Facultad de Geología, Universidad Complutense de Madrid, 28040 Madrid, Spain \\ bepartamento de Química Agrícola, Geología y Geoquímica, Facultad de Ciencias, Universidad Autónoma de Madrid, \\ 28049 Madrid, Spain \\ ${ }^{\mathrm{c}}$ Centro Nacional de Investigaciones Metalúrgicas (C.S.I.C) Avda. Gregorio del Amo, 8, 28040 Madrid, Spain
}

Received 1 October 1997; accepted 4 December 1997

\begin{abstract}
Here we consider the total content of several heavy metals ( $\mathrm{Fe}, \mathrm{Mn}, \mathrm{Cd}, \mathrm{Co}, \mathrm{Cr}, \mathrm{Cu}, \mathrm{Ni}, \mathrm{Pb}$ and $\mathrm{Zn}$ ) and their more bioavailable fractions, corresponding to the soluble and exchangeable forms, in soils surrounding a vehicles scrapyard, compared with a control soil which is not affected. We observed that there is a significative increase in the total contents of $\mathrm{Pb}, \mathrm{Cd}, \mathrm{Cr}, \mathrm{Cu}, \mathrm{Ni}$ and $\mathrm{Zn}$ and also in $\mathrm{Fe}$ and $\mathrm{Mn}$ oxides, mainly amorphous, in the soils closer to the source, which clearly decrease with distance. The upper level of these soils $(0-2 \mathrm{~cm})$ contains the highest content of heavy metals and $\mathrm{Fe}$ and $\mathrm{Mn}$ oxides, which decrease with depth. Nevertheless, the extractable contents (extracted with ammonium acetate of $\mathrm{pH}$ 7) are considerably lower than the total contents, which confirms the high retention capacity of these soils, based upon their calcareous nature, their moderately basic pH (range 7.72-8.09), their significant content of iron oxides (soil constituents of variable charge) and the possible formation of insoluble heavy metals oxides and hydroxides. (c) 1998 Elsevier Science B.V.
\end{abstract}

Keywords: Vehicles scrapyard; Contamination; Heavy metal; Iron oxides

\section{Introduction}

The stores of scrap iron and the activities related with them are a problem of deep environmental concern, mainly in relation to their incidence in surrounding soils. The EC 'Waste Euro-

\footnotetext{
* Corresponding author.
}

pean Strategy 1996' and the EC 'Directive proposal on end-of-life vehicles' have as main objectives to ensure the appropriate conditions for the treatment of the end-of-life vehicles and their reuse, as well as to reduce the environmental impact of the final disposal of such wastes. In Spain it is an especially alarming situation, as the stores of 'out-of-use' vehicles, which are often illegal and uncontrolled, are increasing in number 
at a rate of approx. 1 million discarded automobiles per year (MOPTMA, 1993) and also due to the high potential of environmental risk of their components. Environmental impact studies carried out on these vehicle stores reveal lead, cadmium, zinc and copper as the main inorganic contaminants among trace elements, as well as oil, brake liquid and lubricants as organic contaminants (IHOBE, 1994). The more contaminating activities are the mechanical processes (pressing, grinding and separation into fractions of scrap iron) which cause the spilling of vehicle fluids and the production of iron cuttings and machined pieces which penetrate into the soil profile and result in the progressive deterioration of the soil's quality in the neighbourhood of the vehicles scrapyards.

The aim of this work is to evaluate the variations in the contents of several metallic elements ( $\mathrm{Fe}, \mathrm{Mn}, \mathrm{Cd}, \mathrm{Cr}, \mathrm{Cu}, \mathrm{Ni}, \mathrm{Pb}$ and $\mathrm{Zn}$ ) involved in the activities of scrap iron treatment and store of discarded vehicles, in the soils around a vehicle scrapyard. The contaminant impact of these metals will be evaluated by determination of the total and readily extractable contents, taking into account the characteristics of these soils.

\section{Materials and methods}

The area of study is located in the surroundings of a vehicle scrapyard, in the industrial zone of San Martin de la Vega (Madrid, Spain). The prevailing climate is xeric, with a marked dry summer period, low pluviometric values and high evapotranspiration coinciding with the highest

Table 1

Composition of standard reference material $\mathrm{SO}-3$

\begin{tabular}{lcc}
\hline Element & \multicolumn{1}{l}{$\begin{array}{l}\text { Certified } \\
\text { values }\end{array}$} & $\begin{array}{l}\text { Experimental } \\
\text { values }\end{array}$ \\
\hline $\mathrm{Fe}$ & $1.51 \pm 0.05 \%$ & $1.54 \pm 0.05 \%$ \\
$\mathrm{Mn}$ & $0.052 \pm 0.001 \%$ & $0.052 \pm 0.006 \%$ \\
$\mathrm{Co}$ & $8 \pm 3 \mu \mathrm{g} \mathrm{g}^{-1}$ & $7 \pm 1 \mu \mathrm{g} \mathrm{g}^{-1}$ \\
$\mathrm{Cr}$ & $26 \pm 3 \mu \mathrm{g} \mathrm{g}^{-1}$ & $24 \pm 2 \mu \mathrm{g} \mathrm{g}^{-1}$ \\
$\mathrm{Cu}$ & $17 \pm 1 \mu \mathrm{g} \mathrm{g}^{-1}$ & $18 \pm 1 \mu \mathrm{g} \mathrm{g}^{-1}$ \\
$\mathrm{Ni}$ & $16 \pm 3 \mu \mathrm{g} \mathrm{g}^{-1}$ & $14 \pm 3 \mu \mathrm{g} \mathrm{g}^{-1}$ \\
$\mathrm{~Pb}$ & $14 \pm 3 \mu \mathrm{g} \mathrm{g}^{-1}$ & $14 \pm 1 \mu \mathrm{g} \mathrm{g}^{-1}$ \\
$\mathrm{Zn}$ & $52 \pm 3 \mu \mathrm{g} \mathrm{g}^{-1}$ & $51 \pm 1 \mu \mathrm{g} \mathrm{g}^{-1}$ \\
\hline
\end{tabular}

temperatures. The soils representative of this area are calcaric regosols (FAO-UNESCO, 1990). They have been developed by limited pedological processes, due to the nature of the bedrock (carbonates) and the semi-arid climate.

Soil samples $(0-10 \mathrm{~cm})$ were taken following a longitudinal transect at regular intervals of $5 \mathrm{~m}$ from the scrapyard up to a distance of $30 \mathrm{~m}$. Four soil samples were taken at depth intervals of $0-2$, $2-4,4-6$ and $6-10 \mathrm{~cm}$ in a site close to the scrapyard. Abundant calcareous rock was present at a depth of $10 \mathrm{~cm}$, which indicates the low degree of differentiation of the soil profile, according to the poor weathering conditions. In addition to these samples, a control soil was sampled of similar edaphic properties, apparently free of anthropogenic contamination, approx. $2 \mathrm{~km}$ from the deposit of old vehicles.

The determination of the physico-chemical characteristics (Tables 2 and 7) of the target soils by procedures proposed by the Soil Conservation Service (1972), was performed on samples after they were air-dried and sifted through a 2-mm sieve.

Many dissolution techniques using various extractants have been proposed for determination of specific fractions of soil iron oxides. In order to explain and predict adsorption by soil iron oxides,

Table 2

Edaphic characteristics of affected superficial and undisturbed control soils

\begin{tabular}{|c|c|c|c|c|c|c|c|c|}
\hline Soil & $\begin{array}{l}\text { Distance } \\
\text { (m) }\end{array}$ & ${ }^{\mathrm{a}} \mathrm{pH}$ & $\begin{array}{l}\text { E.C. } \\
\text { (dS m }\end{array}$ & $\begin{array}{l}\mathrm{CaCO}_{3} \\
\left.{ }^{1}\right)(\%)\end{array}$ & $\begin{array}{l}{ }_{3}{ }{ }^{O}{ }^{2}{ }^{c} \\
(\%)\end{array}$ & $\begin{array}{l}{ }^{\mathrm{c}} \text { Clay } \\
(\%)\end{array}$ & $\begin{array}{l}\text { Silt } \\
(\%)\end{array}$ & $\begin{array}{l}\text { Sand } \\
(\%)\end{array}$ \\
\hline 1 & 0 & 7.89 & 0.19 & 23.7 & 6.2 & 9.4 & 16.0 & 74.6 \\
\hline 2 & 5 & 7.91 & 0.19 & 32.2 & 7.4 & 11.4 & 16.0 & 72.6 \\
\hline 3 & 10 & 7.87 & 0.21 & 18.7 & 4.7 & 11.4 & 13.3 & 75.3 \\
\hline 4 & 15 & 8.09 & 0.17 & 21.2 & 2.6 & 13.4 & 14.0 & 72.6 \\
\hline 5 & 20 & 7.99 & 0.24 & 35.7 & 10.8 & 14.9 & 11.8 & 73.3 \\
\hline 6 & 25 & 7.93 & 0.24 & 43.2 & 7.4 & 12.9 & 17.8 & 69.3 \\
\hline 7 & 30 & 7.72 & 0.27 & 38.7 & 9.6 & 10.8 & 12.6 & 76.6 \\
\hline Mean & 一 & 7.91 & 0.21 & 30.5 & 6.9 & 12.02 & 214.5 & 73.4 \\
\hline$\delta$ & - & 0.11 & 0.03 & 9.40 & 2.79 & 1.83 & 32.16 & 52.35 \\
\hline V.C. & 一 & 1 & 16 & 30 & 40 & 15 & 14 & 3 \\
\hline \multicolumn{2}{|c|}{ Control 2000} & 8.00 & 0.30 & 31.5 & 5.7 & 15.0 & 13.6 & 71.4 \\
\hline
\end{tabular}

\footnotetext{
${ }^{\mathrm{a}}$ Distance from the yard.

${ }^{\mathrm{b}}$ Electrical conductivity.

${ }^{\mathrm{c}}$ Organic matter.
} 
it seems more worthwhile to use methods which determine the capacity of adsorption, rather than techniques that identify individual minerals. Soil iron oxides are commonly considered to contain a continuum of compounds ranging from highly reactive (readily extractable) to unreactive (unextractable). Schwertmann (1973) proposed an oxalate solution technique which excluded light for the extraction of what he called the 'active' fraction of soil iron oxides. The oxalate technique may be a very convenient method for estimating non-crystalline (amorphous) and poorly crystalline iron oxides in soils (Borggaard, 1990). Dithionite-extractable iron oxide methods are based on the reduction of iron (III) to iron (II) by means of the very strong reductant dithionite and the addition of a ligand to complex the iron released and keep it in solution. This method is used for determination of total and/or free iron oxides.

In this work, a sequential extraction of the iron oxides with different degrees of crystallinity was performed. In an initial stage, the amorphous and poorly crystalline iron oxides were extracted in darkness with ammonium oxalate buffered at $\mathrm{pH}$ 3.2 (McKeague and Day, 1966; Schwertmann, 1973). In a second stage, the residual was treated with a solution of sodium citrate and sodium bicarbonate using sodium dithionite as a reducing agent to dissolve the more crystallized iron oxides (Mehra and Jackson, 1960).

The heavy metals total contents were determined after their dissolution with acid-oxidant reagents mixture $\left(\mathrm{HNO}_{3} / \mathrm{H}_{2} \mathrm{O}_{2}\right.$ and $\left.\mathrm{HCl}\right)$ by refluxing (EPA, 1990). The readily bioavailable metal fraction was extracted with $1 \mathrm{~N}$ ammonium acetate solution buffered at $\mathrm{pH} 7$ (Tessier et al., 1979). Suprapur quality reagents were used for all the procedures. The total and extractable metal contents of these soil samples were determined by inductively-coupled plasma atomic emission spectroscopy with a Jobin-Yvon JY-70 instrument.

In order to verify the detection sensitivity of the equipment under operating conditions used, the detection limit (DL) was defined as the concentration which gives a net signal equal to three times the standard deviation of the background level (3 S.D.). This detection limit was determined using digestion and extraction solutions with a concentration of each analyte of $1 \mu \mathrm{g} \mathrm{ml}^{-1}$.

The precision and the accuracy of the analytical procedure were evaluated with the soil standard reference material, CRM SO-3 CANMET (Canada Centre for Mineral and Energy Technology). Concentration values and uncertainty limits for the analysis of the certified elements in the standard reference material are reported in Table 1. Each value is the average of five measurements and each measurement was made on a different sample. The results obtained for both major and minor elements are in good agreement with the certified values.

\section{Results and discussion}

The soils studied (Table 2) are moderately basic ( $\mathrm{pH}$ range 7.72-8.09), with high contents of carbonate (range 18.7-43.2\%). The values of electrical conductivities (range $0.17-0.27 \mathrm{mS}$ $\mathrm{cm}^{-1}$ ) confirms the low content of soluble salts. The organic matter content is greater than $10 \%$ in some samples. The texture of these soils is sandy loam (FAO, 1977). The control soil has similar edaphic properties to the target soils.

Soil samples $(0-10 \mathrm{~cm})$ closer to the scrap iron deposit show higher contents of iron oxides,

Table 3

Amorphous (oxalate-extracted) and crystalline (dithionite-extracted) iron oxide contents of affected superficial and undisturbed control soils

\begin{tabular}{lccc}
\hline Soil & $\begin{array}{l}\text { Distance } \\
(\mathrm{m})\end{array}$ & $\begin{array}{l}\text { Amorphous } \\
\mathrm{Fe}_{2} \mathrm{O}_{3} \\
(\%)\end{array}$ & $\begin{array}{l}\text { Crystalline } \\
\mathrm{Fe}_{2} \mathrm{O}_{3} \\
(\%)\end{array}$ \\
\hline 1 & 0 & 2.94 & 0.53 \\
2 & 5 & 1.42 & 0.21 \\
3 & 10 & 0.53 & 0.24 \\
4 & 15 & 0.22 & 0.25 \\
5 & 20 & 0.27 & 0.23 \\
6 & 25 & 0.18 & 0.22 \\
7 & 30 & 0.26 & 0.23 \\
Mean & - & 0.83 & 0.27 \\
$\delta$ & - & 1.02 & 0.11 \\
V.C. & - & 123 & 41 \\
Control & 2000 & 0.04 & 0.14 \\
\hline
\end{tabular}


Table 4

Total metals contents of affected superficial and undisturbed control soils

\begin{tabular}{lcccccccccc}
\hline Soil & $\begin{array}{l}\text { Distance }^{\mathrm{a}} \\
(\mathrm{m})\end{array}$ & $\begin{array}{l}\mathrm{Fe} \\
(\%)\end{array}$ & $\begin{array}{l}\mathrm{Mn} \\
(\%)\end{array}$ & $\begin{array}{l}\mathrm{Cd} \\
\left(\mu \mathrm{g} \mathrm{g}^{-1}\right)\end{array}$ & $\begin{array}{l}\mathrm{Co} \\
\left(\mu \mathrm{gg}^{-1}\right)\end{array}$ & $\begin{array}{l}\mathrm{Cr} \\
\left(\mu \mathrm{g} \mathrm{g}^{-1}\right)\end{array}$ & $\begin{array}{l}\mathrm{Cu} \\
\left(\mu \mathrm{g} \mathrm{g}^{-1}\right)\end{array}$ & $\begin{array}{l}\mathrm{Ni} \\
\left(\mu \mathrm{g} \mathrm{g}^{-1}\right)\end{array}$ & $\begin{array}{l}\mathrm{Pb} \\
\left(\mu \mathrm{g} \mathrm{g}^{-1}\right)\end{array}$ & $\begin{array}{l}\mathrm{Zn} \\
\left(\mu \mathrm{g} \mathrm{g}^{-1}\right)\end{array}$ \\
\hline 1 & 0 & 2.12 & 0.027 & 11.6 & 19.6 & 277.3 & 610.8 & 53.4 & 2004 & 1991 \\
2 & 5 & 1.52 & 0.028 & 7.4 & 16.0 & 146.8 & 307.9 & 35.0 & 1043 & 1659 \\
3 & 10 & 1.32 & 0.022 & 3.3 & 14.4 & 81.9 & 150.7 & 24.1 & 651.1 & 930.5 \\
4 & 15 & 1.16 & 0.017 & 2.3 & 10.2 & 43.5 & 115.4 & 17.7 & 429.1 \\
5 & 20 & 0.80 & 0.013 & 2.5 & 8.2 & 33.8 & 94.3 & 15.4 & 388.7 & 544.5 \\
6 & 25 & 0.84 & 0.011 & 2.2 & 8.1 & 32.9 & 89.1 & 13.9 & 357.0 & 439.0 \\
7 & 30 & 0.77 & 0.009 & 2.1 & 7.6 & 29.4 & 85.5 & 12.7 & 353.2 & 414.5 \\
Mean & - & 1.21 & 0.018 & 4.48 & 12.0 & 92.2 & 207.6 & 24.6 & 746.6 & 934.8 \\
$\delta$ & - & 0.49 & 0.007 & 3.65 & 4.68 & 91.8 & 194.1 & 14.8 & 607.4 & 638.4 \\
V.C. & - & 40 & 42 & 81 & 39 & 99 & 93 & 60 & 81 & 68 \\
Control & 2000 & 0.76 & 0.008 & 0.62 & 6.0 & 18.6 & 16.5 & 8.8 & 13.5 \\
\hline
\end{tabular}

${ }^{\text {a }}$ Distance from the yard.

$\mathrm{DL}_{\operatorname{exp~Cd}}=0.056 \mu \mathrm{g}^{-1} \mathrm{~g} ; \mathrm{DL}_{\operatorname{exp~Co}}=0.445 \mu \mathrm{g} \mathrm{g}^{-1} ; \mathrm{DL}_{\operatorname{exp~Cr}}=0.142 \mu \mathrm{g} \mathrm{g}^{-1} ; \mathrm{DL}_{\operatorname{exp~Cu}}=0.126 \mu \mathrm{g} \mathrm{g}^{-1} ; \mathrm{DL}_{\operatorname{exp~Ni}}=0.743 \mu \mathrm{g} \mathrm{g}^{-1}$; $\mathrm{DL}_{\operatorname{exp~Pb}}=0.653 \mu \mathrm{g} \mathrm{g}^{-1} ; \mathrm{DL}_{\operatorname{exp~Zn}}=0.079 \mu \mathrm{g} \mathrm{g}^{-1}$.

mainly amorphous, than the control soil (Table 3 ), probably as consequence of the deposition of metallic particles. A decrease of these contents with distance is detected, although further soil samples (at $30 \mathrm{~m}$ from the yard) also show higher values than the control sample.

Soil samples $(0-10 \mathrm{~cm})$ show, for all the target elements, remarkably higher contents than the control sample (Table 4) and a tendency of a progressive decrease with distance from the storage site. This gradual decrease with distance may indicate a possible mechanical dispersion of the contaminants by atmospheric deposition of the sub-products originating from scrap iron cutting, pressing and storing activities. This distribution tendency has been already confirmed in other contaminant activities, such as smelting, which cause the deposition of metallic particles on the

Table 5

Correlation coefficients among total metal contents and amorphous (oxalate-extracted $\mathrm{Fe}_{2} \mathrm{O}_{3}$ ) and crystalline (dithionite-extracted $\mathrm{Fe}_{2} \mathrm{O}_{3}$ ) iron oxides of affected superficial and undisturbed control soils

\begin{tabular}{|c|c|c|c|c|c|c|c|c|c|c|c|}
\hline & $\mathrm{Cd}$ & $\mathrm{Zn}$ & Co & $\mathrm{Cu}$ & $\mathrm{Cr}$ & $\mathrm{Ni}$ & $\mathrm{Pb}$ & $\mathrm{Mn}$ & $\mathrm{Fe}$ & $\mathrm{Fe}_{2} \mathrm{O}_{3}{ }^{\mathrm{a}}$ & $\mathrm{Fe}_{2} \mathrm{O}_{3}{ }^{\mathrm{b}}$ \\
\hline $\mathrm{Cd}$ & 1 & & & & & & & & & & \\
\hline $\mathrm{Zn}$ & 0.971 & 1 & & & & & & & & & \\
\hline Co & 0.913 & 0.968 & 1 & & & & & & & & \\
\hline $\mathrm{Cu}$ & n.s. & 0.803 & n.s. & 1 & & & & & & & \\
\hline $\mathrm{Cr}$ & 0.991 & 0.960 & 0.933 & n.s. & 1 & & & & & & \\
\hline $\mathrm{Ni}$ & 0.988 & 0.978 & 0.958 & n.s. & 0.966 & 1 & & & & & \\
\hline $\mathrm{Pb}$ & 0.988 & 0.992 & 0.973 & 0.803 & 0.969 & 0.978 & 1 & & & & \\
\hline $\mathrm{Mn}$ & 0.832 & 0.929 & 0.964 & n.s. & 0.840 & 0.821 & 0.885 & 1 & & & \\
\hline $\mathrm{Fe}$ & 0.938 & 0.947 & 0.973 & n.s. & 0.965 & 0.974 & 0.929 & 0.918 & 1 & & \\
\hline $\mathrm{Fe}_{2} \mathrm{O}_{3}{ }^{\mathrm{a}}$ & 0.994 & 0.946 & 0.897 & n.s. & 0.995 & 0.986 & 0.966 & n.s. & 0.937 & 1 & \\
\hline $\mathrm{Fe}_{2} \mathrm{O}_{3}{ }^{\mathrm{b}}$ & 0.817 & n.s. & n.s. & n.s. & 0.859 & 0.821 & n.s. & n.s. & 0.797 & 0.871 & 1 \\
\hline
\end{tabular}

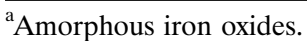

${ }^{\mathrm{b}}$ Crystalline iron oxides.

Significance levels: $P<0.05, r=0.755 ; P<0.01, r=0.875 ; P<0.001, r=0.981$; n.s., not significant.
} 
Table 6

Extractable heavy metal contents of affected superficial and undisturbed control soils

\begin{tabular}{|c|c|c|c|c|c|c|c|c|}
\hline Soils & $\begin{array}{l}\text { Distance } \\
(\mathrm{m})\end{array}$ & $\begin{array}{l}\mathrm{Cd} \\
\left(\mu \mathrm{g} \mathrm{g}^{-1}\right)\end{array}$ & $\begin{array}{l}\text { Co } \\
\left(\mu \mathrm{gg}^{-1}\right)\end{array}$ & $\begin{array}{l}\mathrm{Cr} \\
\left(\mu \mathrm{gg}^{-1}\right)\end{array}$ & $\begin{array}{l}\mathrm{Cu} \\
\left(\mu \mathrm{g} \mathrm{g}^{-1}\right)\end{array}$ & $\begin{array}{l}\mathrm{Ni} \\
\left(\mu \mathrm{gg}^{-1}\right)\end{array}$ & $\begin{array}{l}\mathrm{Pb} \\
\left(\mu \mathrm{gg}^{-1}\right)\end{array}$ & $\begin{array}{l}\mathrm{Zn} \\
\left(\mu \mathrm{g} \mathrm{g}^{-1}\right)\end{array}$ \\
\hline 1 & 0 & 1.7 & $<\mathrm{DL}$ & $<\mathrm{DL}$ & 23.0 & $<\mathrm{DL}$ & 141.5 & 139.2 \\
\hline 2 & 5 & 0.8 & $<\mathrm{DL}$ & $<\mathrm{DL}$ & 36.9 & $<\mathrm{DL}$ & 60.6 & 46.7 \\
\hline 3 & 10 & 0.2 & $<\mathrm{DL}$ & $<\mathrm{DL}$ & 3.3 & $<\mathrm{DL}$ & 24.7 & 18.4 \\
\hline 4 & 15 & $<\mathrm{DL}$ & $<\mathrm{DL}$ & $<\mathrm{DL}$ & 1.0 & $<\mathrm{DL}$ & 15.5 & 10.6 \\
\hline 5 & 20 & $<\mathrm{DL}$ & $<\mathrm{DL}$ & $<\mathrm{DL}$ & 1.0 & $<\mathrm{DL}$ & 11.4 & 13.4 \\
\hline 6 & 25 & $<\mathrm{DL}$ & $<\mathrm{DL}$ & $<\mathrm{DL}$ & 2.9 & $<\mathrm{DL}$ & 9.3 & 13.1 \\
\hline 7 & 30 & $<\mathrm{DL}$ & $<\mathrm{DL}$ & $<\mathrm{DL}$ & 1.3 & $<\mathrm{DL}$ & 13.0 & 16.2 \\
\hline Mean & - & - & - & - & 11.4 & - & 39.4 & 36.8 \\
\hline$\delta$ & - & - & - & - & 15.0 & - & 48.4 & 46.8 \\
\hline V.C. & - & - & - & - & 132 & - & 122 & 127 \\
\hline Control & 2000 & $<\mathrm{DL}$ & $<\mathrm{DL}$ & $<\mathrm{DL}$ & $<\mathrm{DL}$ & $<\mathrm{DL}$ & $<\mathrm{DL}$ & $<\mathrm{DL}$ \\
\hline
\end{tabular}

$\mathrm{DL}_{\operatorname{exp~Cd}}=0.133 \mu \mathrm{g} \mathrm{g}^{-1} ; \mathrm{DL}_{\operatorname{exp~Co}}=0.869 \mu \mathrm{g} \mathrm{g}^{-1} ; \mathrm{DL}_{\operatorname{exp~Cr}}=0.190 \mu \mathrm{g} \mathrm{g}^{-1} ; \mathrm{DL}_{\operatorname{exp~Cu}}=0.134 \mu \mathrm{g} \mathrm{g}^{-1} ; \mathrm{DL}_{\operatorname{exp~Ni}}=0.794 \mu \mathrm{g} \mathrm{g}^{-1}$; $\mathrm{DL}_{\operatorname{exp~Pb}}=0.974 \mu \mathrm{g} \mathrm{g}^{-1} ; \mathrm{DL}_{\operatorname{exp~Zn}}=0.854 \mu \mathrm{g} \mathrm{g}^{-1}$.

surrounding soils, due to the eolian dispersion (Little and Martin, 1972; Etling, 1985; Dudka, 1995).

The highly significant correlation among the total contents of the elements determined (with the exception of $\mathrm{Cu}$ ) as well as with the oxides iron contents (mainly those oxalate-extracted) (Table 5), seem to verify a common origin of the metallic contamination of these soils, which is due to the scrapyard activities. No significant correlation among total metals contents and the rest of the edaphic properties studied in these soils have been observed.

The main contents of $\mathrm{Cd}, \mathrm{Pb}$ and $\mathrm{Zn}$ determined in the affected soils are higher than the concentration limit values for heavy metals in soils with $\mathrm{pH}>7$, reported in the European Com-

Table 7

Edaphic characteristics of soils taken at depth intervals

\begin{tabular}{lcllllll}
\hline $\begin{array}{l}\text { Depth } \\
\text { intervals } \\
(\mathrm{cm})\end{array}$ & $\mathrm{pH}$ & $\begin{array}{l}\text { E.C. }^{\mathrm{a}} \\
\left(\mathrm{dS} \mathrm{m}{ }^{-1}\right)\end{array}$ & $\begin{array}{l}\mathrm{CaCO}_{3} \\
(\%)\end{array}$ & $\begin{array}{l}\text { O.M. }^{\mathrm{b}} \\
(\%)\end{array}$ & $\begin{array}{l}\text { Clay } \\
(\%)\end{array}$ & $\begin{array}{l}\text { Silt } \\
(\%)\end{array}$ & $\begin{array}{l}\text { Sand } \\
(\%)\end{array}$ \\
\hline $0-2$ & 8.14 & 0.15 & 18.7 & 3.3 & 17.6 & 13.3 & 69.1 \\
$2-4$ & 8.19 & 0.19 & 25.2 & 5.9 & 18.9 & 10.5 & 70.6 \\
$4-6$ & 8.22 & 0.17 & 25.7 & 6.3 & 18.9 & 12.5 & 68.6 \\
$6-10$ & 8.19 & 0.17 & 30.7 & 2.0 & 18.7 & 14.7 & 66.6 \\
\hline
\end{tabular}

${ }^{\text {a }}$ Electrical conductivity.

${ }^{\mathrm{b}}$ Organic matter. munity Directive 86/181. The high concentrations of $\mathrm{Cu}$ and $\mathrm{Cr}$ in the soil samples $(0-10 \mathrm{~cm})$ closer to the contaminant source are also remarkable.

The extractable contents of the soil $(0-10 \mathrm{~cm})$ and control samples, which correspond to the more bioavailable forms of these metals (soluble and/or exchangeable forms of these metals as well as a certain fraction of metal associated with carbonates of these soils) (Tessier et al., 1979), are reported in Table 6 . These extractable contents are much lower than the total, which may be explained by the high retention capacity of these soils due mainly to their calcareous nature. Carbonate minerals are major components of calcareous soils and provide the main adsorptive surfaces for heavy metals (McBride, 1980; Pickering, 1982). The presence of carbonate minerals in

Table 8

Amorphous (oxalate-extracted) and crystalline (dithionite-extracted) iron oxide contents of soils taken at depth intervals

\begin{tabular}{lll}
\hline $\begin{array}{l}\text { Depth intervals } \\
(\mathrm{cm})\end{array}$ & $\begin{array}{l}\text { Amorphous } \\
\mathrm{Fe}_{2} \mathrm{O}_{3} \\
(\%)\end{array}$ & $\begin{array}{l}\text { Crystalline } \\
\mathrm{Fe}_{2} \mathrm{O}_{3} \\
(\%)\end{array}$ \\
\hline $0-2$ & 0.23 & 0.19 \\
$2-4$ & 0.14 & 0.08 \\
$4-6$ & 0.07 & 0.05 \\
$6-10$ & 0.05 & 0.05 \\
\hline
\end{tabular}



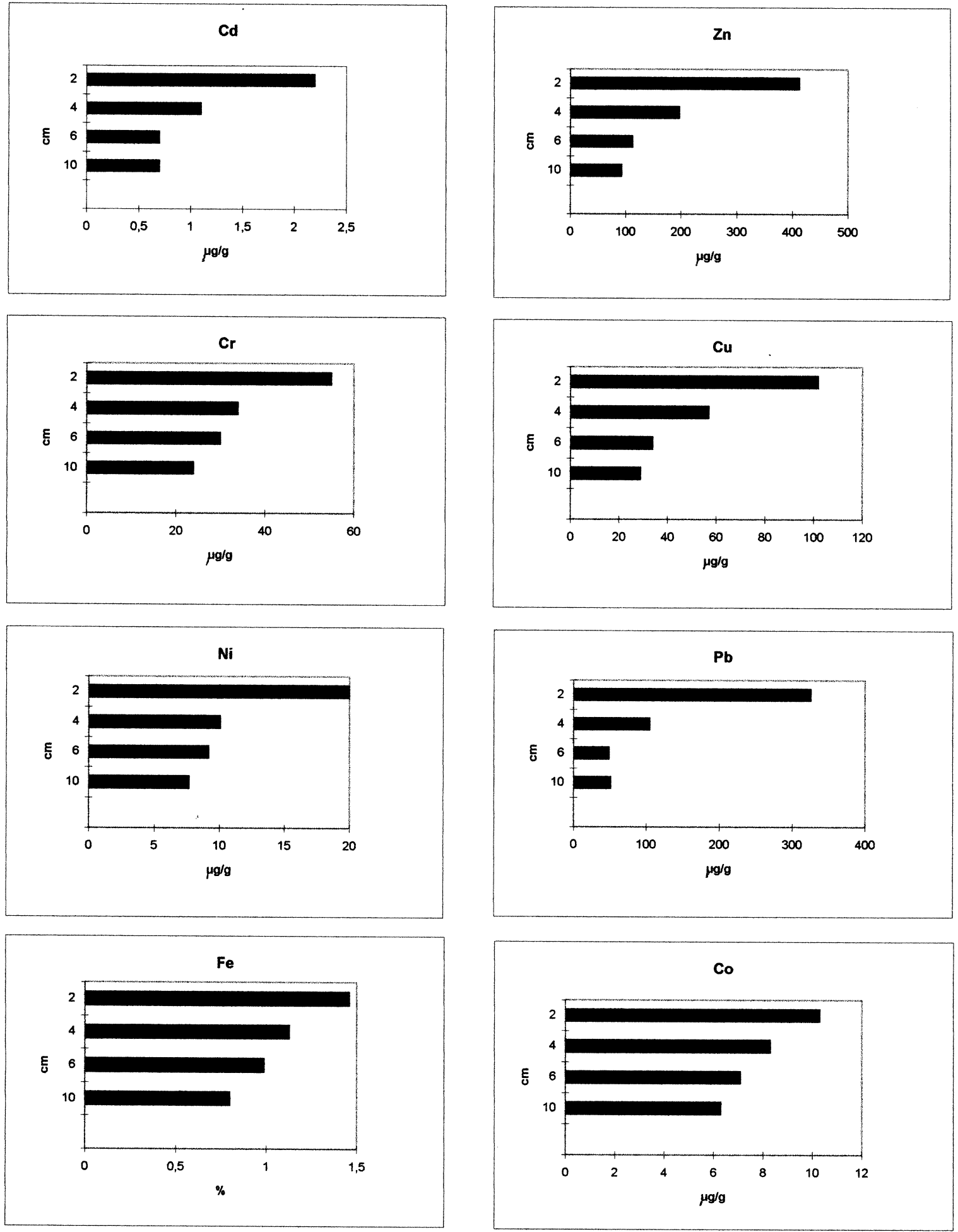

Fig. 1. Total metal content of soil vs. depth of sample. 
soils may have direct and indirect effects on heavy metal mobility and reactivity. According to $\mathrm{Pa}-$ padopoulos and Rowell (1988), direct through their surface interactions with metals and indirect through their effect on soil $\mathrm{pH}$, because increased $\mathrm{pH}$ values usually result in an increase of soil adsorptive capacity. It is noticeable that these soils show high values of iron oxides which increase their adsorption capacity of heavy metals at basic $\mathrm{pH}$ (Barrow, 1985). The formation of insoluble precipitates of heavy metal oxides and hydroxides is also likely to take place under these edaphic conditions. Nevertheless, the extractable contents of $\mathrm{Pb}, \mathrm{Zn}, \mathrm{Cd}$ and $\mathrm{Cu}$ of the soil samples $(0-10 \mathrm{~cm})$ closer to the scrapyard are higher than control soil contents [lower than the detection limit (DL) for the elements] and could cause a potential risk, considering that they are the bioavailable fractions of these metals.

The soil samples taken at various depth intervals show relevantly homogeneous values of the physico-chemical parameters determined, with the only exception of the different fraction of iron oxides (Tables 7 and 8). These oxides are clearly higher in the upper level $(0-2 \mathrm{~cm})$ than in the other levels, probably as a consequence of the superficial deposition of the products of the contaminant activities. Furthermore, a gradual decrease of the amorphous iron oxides with depth, as well as a sharp decrease of the dithionite-extractable iron oxides from the upper level $(0-2$ $\mathrm{cm})$ to the second level $(2-4 \mathrm{~cm})$ are also detected.

The total metal contents of the depth soil samples are illustrated in Fig. 1. A generalized enrichment of the superficial level $(0-2 \mathrm{~cm})$ and a gradual decrease with depth are observed for all the target elements. This distribution pattern is similar to the one shown by the amorphous iron oxides.

\section{Conclusions}

As a consequence of the activities carried out in a vehicles scrapyard, a large increase in the heavy metal content, mainly $\mathrm{Cd}, \mathrm{Pb}$ and $\mathrm{Zn}$, as well as an increase in the contents of the different soil iron oxide fractions are observed. These contents strongly decrease with the distance from the vehicles scrapyard and even at a distance of $30 \mathrm{~m}$, the affected soils show higher contents than a control soil of similar physico-chemical properties which was not affected by the contaminant source.

This decrease confirms eolian dispersion as a route for contamination by deposition of metallic particles over the surrounding soils. This dispersion is confirmed by the enrichment of the superficial level $(0-2 \mathrm{~cm})$ by $\mathrm{Fe}$ and $\mathrm{Mn}$ oxides as well as heavy metals. Despite the high total contents of heavy metals of the affected soils (which in the case of $\mathrm{Pb}, \mathrm{Cd}, \mathrm{Zn}, \mathrm{Cu}$ and $\mathrm{Cr}$ are higher than the concentration limit values established by the $\mathrm{Eu}-$ ropean Community legislation), a low degree of bioavailability as well as a low mobility in the soil profile is observed. This could be explained by the calcareous nature of these soils as well as by the significant content of $\mathrm{Fe}$ and $\mathrm{Mn}$ oxides, which have a high retention potential of heavy metals at basic $\mathrm{pH}$.

\section{References}

Barrow NJ. Reaction of anions and cations with variable charge soils. Adv Agron 1985;38:183-230.

Borggaard OK. Dissolution and adsorption properties of soil iron oxides. Chemistry Department. Royal Veterinary and Agricultural University. Copenhagen, Denmark, 1990:122.

Dudka S. Trace metal contamination of soils of crop plants by the mining and smelting industry of Upper Silesia, South Poland. J Geol Explor 1995;52:237-250.

EPA. Acid digestion of sediments, sludges and soils. Method 3050A. Environmental Protection Agency, 1990.

Etling D. Emission of contaminated dust from sludge deposits. Contam Soil'88 1985;2:1429-1430.

FAO. Guía para la descripción de perfiles de suelos. 2nd ed. Servicio de Fomento y conservación de recursos de suelos. Dirección de Fomento de Tierras y Aguas. Organización de las Naciones Unidad para la Agricultura y la Alimentación, Roma, 1977.

FAO-UNESCO. Soil map of the world. Revised legend. World soil resources report, 60. Rome: FAO, 1990.

IHOBE. Guía Metodológica de investigación de la contaminación del suelo. Plan Director para la Protección del Suelo. Gobierno Vasco, 1994.

Little P, Martin MA. A survey of zinc, lead and cadmium in soil and natural vegetation around a smelting complex. Environ Pollut 1972;3:241-254.

McBride MB. Chemisorption of $\mathrm{Cd}^{+2}$ on calcite surfaces. Soil Sci Soc Am J 1980;44:26-28. 
McKeague JM, Day JH. Dithionite and oxalate extractable Fe and $\mathrm{Al}$ as aids in differentiating various classes of soils. Can J Soil Sci 1966;46:13-22.

Mehra OP, Jackson ML. Iron oxide removal from soils and clays by a dithionite-citrate system buffered with sodium bicarbonate. Clays Clay Miner 1960;7:317-327.

MOPTMA. Libro blanco de residuos del Ministerio de Obras Públicas. Transporte y Medio Ambiente (MOPTMA), 1993.

Papadopoulos P, Rowell DL. The reactions of cadmium with calcium carbonate surface. J Soil Sci 1988;39:23-26.

Pickering WF. Extraction of copper, lead, zinc and cadmium sorbed on calcium carbonate. Water Air Soil Pollut 1982;20:299-309.

Schwertmann W. Use of oxalate for iron oxide extraction from soils. Can J Soil Sci 1973;53:244-246.

Soil Conservation Service. Soil survey laboratory methods and procedures for collecting soil samples. US Department of Agriculture, 1972:63.

Tessier A, Campbell PGC, Bissor M. Sequential extraction procedure from the speciation of particulate trace metals. Anal Chem 1979;51:844-851. 